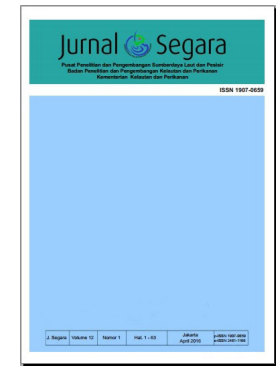

JURNAL SEGARA

http://ejournal-balitbang.kkp.go.id/index.php/segara

ISSN : 1907-0659

e-ISSN : 2461-1166

Nomor Akreditasi: 766/AU3/P2MI-LIPI/10/2016

\title{
POTENSI SIMPANAN KARBON PADA BIOMASSA TEGAKAN DAN AKAR MANGROVE DI KAWASAN LINDUNG PANTAI PULAU PAYUNG, KABUPATEN BANYUASIN
}

\section{POTENTIAL OF CARBON STORAGE ON STANDS AND ROOTS BIOMASS OFMANGROVE IN THE PROTECTED PAYUNG ISLAND AREA, BANYUASIN DISTRICT}

\author{
Septi Hermialingga1), Rujito Agus Suwignyo²), \& Tengku Zia Ulqodry3) \\ 1)Program Studi Pengelolaan Lingkungan, Program Pascasarjana, Universitas Sriwijaya \\ 2)Program Studi Budidaya Pertanian, Fakultas Pertanian, Universitas Sriwijaya \\ ${ }^{3}$ Program Studi IImu Kelautan, Fakultas MIPA, Universitas Sriwijaya
}

Diterima: 18 September 2020; Diterima Setelah Perbaikan: 27 November 2020; Disetujui Terbit: 16 Desember 2020

\begin{abstract}
ABSTRAK
Mangrove sangat efektif mengurangi karbon di atmosfer yang kemudian disimpan dalam bentuk biomassa. Penelitian ini bertujuan untuk melakukan estimasi simpanan karbon pada tegakan dan akar mangrove. Penelitian ini dilakukan pada Februari 2020 di Pulau Payung, Kecamatan Banyuasin menggunakan metode purposive sampling. Perhitungan biomassa mangrove menggunakan metode persamaan allometrik. Hasil estimasi simpanan karbon dari biomassa tegakan dan akar mangrove yang terbesar yaitu jenis mangrove $A$. alba sedangkan yang terkecil yaitu jenis mangrove $X$. granatum. Biomassa dan stok karbon tegakan mangrove tiap stasiun yang tertinggi terdapat pada stasiun 2 dan terendah terdapat pada stasiun 6 . Tegakan mangrove memiliki nilai rata-rata biomassa dan simpanan karbon yaitu 124,4 ton/ha dan 58,47 tonC/ha. Akar mangrove memiliki nilai ratarata biomassa dan simpanan karbon yaitu 71,44 ton/ha dan 33,58 tonC/ha.
\end{abstract}

Kata Kunci : Simpanan karbon, Biomassa, Mangrove, Pulau Payung.

\section{ABSTRACT}

Mangrove are very effective at reducing carbon in the atmosphere which is then transferred in the form of biomass. This research estimated carbon storage in mangrove stands and roots. This research was conducted at 8-9 February 2020 in Payung Island, Banyuasin District using a purposive sampling method. The calculation of mangrove biomass used the allometric calculation method. Mangrove $A$. alba showed the highest carbon storage of standing biomass and mangrove roots compared with other mangrove species. The highest biomass and carbon stock of mangrove stand at each station 2 and the lowest is at station 6. Mangrove stands had an average value of biomass and carbon storage of 124.4 ton/ha and 58.47 tonC/ ha. Mangrove forests had an average value of biomass and carbon stock which is 71.44 ton/ha and 33.58 tonC/ha.

Keywords: Storage Carbon, Biomass, Mangrove, Payung Island.

Corresponding author:

Jl. Pasir Putih I Ancol Timur, Jakarta Utara 14430. Email: zia_uul@unsri.ac.id 


\section{PENDAHULUAN}

Ekosistem mangrove merupakan vegetasi unik yang hidup di zona pasang surut air laut (Mustofa, 2018), dan merupakan tumbuhan yang mempunyai peranan penting utama di lingkungan pesisir (Ulqodry et al., 2014). Menurut Karimah (2017) Indonesia memiliki hutan mangrove terluas di Asia bahkan dunia dengan luas kurang lebih 3,7 juta hektar dan secara ekologi ekosistem mangrove berfungsi sebagai tempat mencari makanan bagi biota dengan banyaknya bahan organik, tempat bertelur dan tempat pengasuhan biota perairan. Selain itu, vegetasi mangrove dapat berfungsi sangat efektif dalam menyerap karbondioksida (Setiawan, 2013).

Pada penelitian Donato et al. (2011) hutan mangrove Indo-Pasifik mampu menyimpan karbon per hektar 4 kali lebih tinggi dari penyimpanan karbon di hutan tropis serta penyerapan karbon pada hutan mangrove 5 kali lebih cepat dibanding hutan tropis lainnya (Imiliyana et al., 2011). Peyimpanan dan penyerapan karbondioksida sangat berperan untuk mengurangi konsentrasi gas $\mathrm{CO}_{2}$ (Suryono et al., 2018). Kepel et al. (2017) menyatakan bahwa mangrove menyimpan karbon dalam biomassa pohon seperti ranting, batang, akar, daun. Simpanan karbon dalam tubuh mangrove juga dapat terlepas sebagai emisi karbon ke atmosfer apabila terjadi degradasi dalam jumlah besar yang akan mempengaruhi pertambahan konsentrasi $\mathrm{CO}_{2}$ di atmosfer (Sondak, 2015).

Pulau Payung merupakan kawasan hutan lindung menurut SK Menhut No. 866/Menhut-II/2014 dengan luas $\pm 490 \mathrm{Ha}$. Pulau Payung terletak di mulut muara Sungai Musi, salah satu sungai terpanjang di Sumatera, yang menjadikannya mendapat pasokan air tawar yang sangat besar setiap harinya. Pulau Payung memiliki potensi mangrove alami terhadap penyerapan karbon dan belum ada penelitian mengenai estimasi biomassa dan simpanan karbon di Pulau Payung. Oleh karena itu, penelitian ini bertujuan untuk mengestimasi besaran simpanan karbon pada biomassa tegakan dan akar mangrove menggunakan metode allometrik sebagai bahan pertimbangan pengambilan kebijakan adanya upaya pengelolaan dan pelestarian mangrove.

\section{METODE PENELITIAN}

\section{Waktu dan Tempat}

Penelitian dilakukan pada Februari 2020 di Pulau Payung, Kabupaten Banyuasin dengan 8 stasiun lokasi pengamatan (Gambar 1). Secara geografis letak Pulau Payung berada pada koordinat $2^{\circ} 22^{\prime} 51^{\prime \prime}$ LS dan $104^{\circ}$ $55^{\prime} 16$ " BT.

\section{Pengambilan Data}

Pengambilan data analisis vegetasi dan biomassa dilakukan dengan metode non destructive menggunakan persamaan allometrik. Komunitas mangrove di Pulau Payung didominasi oleh jenis Nipah. Kondisi ketebalan mangrove sejati yang bukan Nipah relatif tipis yaitu dibawah $100 \mathrm{~m}$. Untuk mengetahui kondisi komposisi mangrove di Pulau Payung dilakukan analisis vegetasi mangrove di 8 titik lokasi pengamatan menggunakan metode transek kuadrat sepanjang 50 $\mathrm{m}$ yang terdiri dari masing-masing 3 plot (10x10 m untuk kategori pohon) (Gambar 2). Selanjutnya diidentifikasi jenis mangrove dan diukur diameter pohon setinggi dada (DBH) di setiap plot (Bismark, 2011).

\section{Analisa Data \\ Analisis Vegetasi}

Analisis vegetasi menghitung Kerapatan Relatif

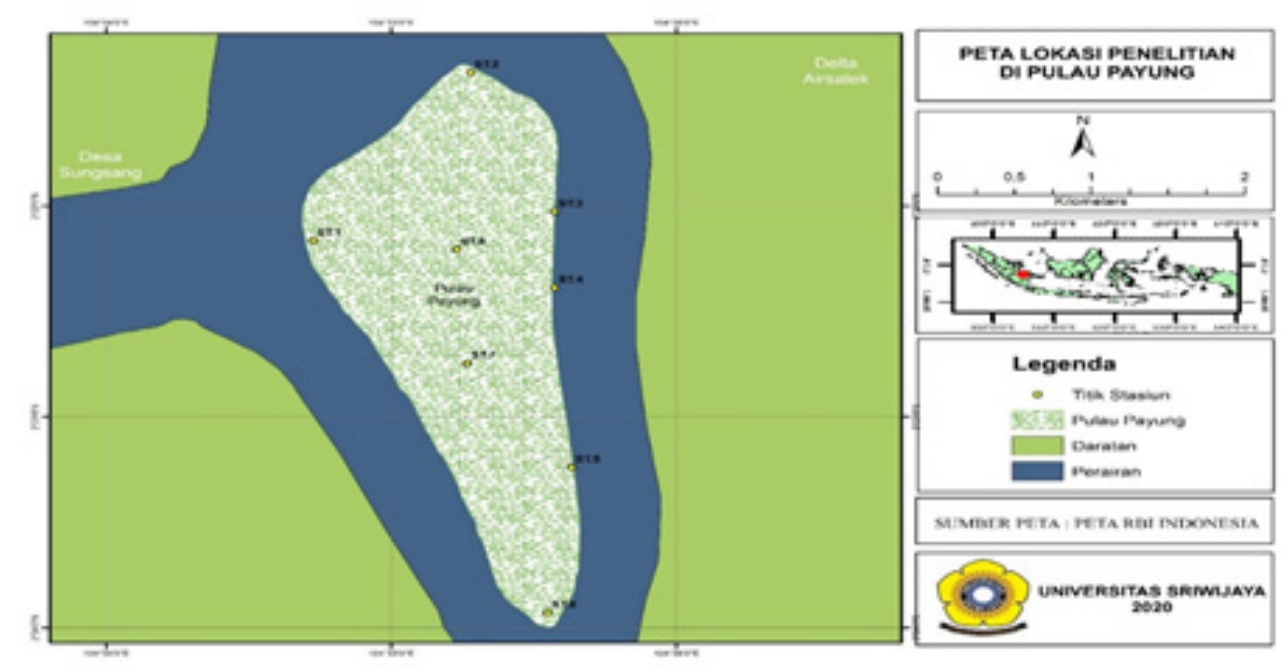

Gambar 1. Peta Lokasi Penelitian. 


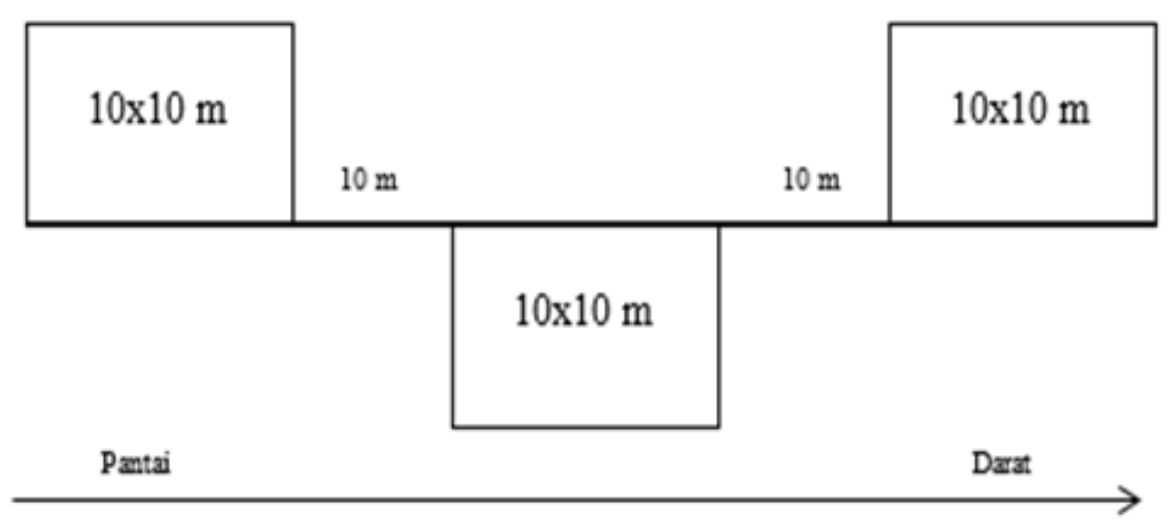

Gambar 2. Desain transek mangrove.

$(\mathrm{KR})$, Frekuensi Relatif (FR), dominasi relatif (DR), dan Indeks Nilai Penting (INP) (Kepel et al., 2017) menggunakan rumus dari (Muller-Dumbois \& Ellenberg, 1974) serta indeks keanekargaman (H') ShannonWiener (Asuk et al., 2018).

Kerapatan Jenis (Ki)

$$
\mathrm{Ki}=\frac{\mathrm{ni}}{\mathrm{A}}
$$$$
\text { A }
$$

dimana,

$\mathrm{ni}=$ jumlah total tegakan jenis-i (individu)

$A=$ Total luas areal plot (ha)

Kerapatan Relatif Jenis (KR)

$$
\mathrm{KR}=\left(\frac{\mathrm{ni}}{\Sigma n}\right) \times 100 \%
$$

dimana,

$\mathrm{ni}=$ Jumlah total tegakan jenis-i (individu)

$\Sigma \mathrm{n}=$ Jumlah total tegakan seluruh jenis (individu)

Frekuensi Jenis $(\mathrm{Fi})$

$$
\mathrm{Fi}=\frac{p \mathrm{i}}{\Sigma p}
$$

dimana,

$\mathrm{Pi}=$ Jumlah plot ditemukan jenis-i

$\Sigma p=$ Jumlah total plot

\section{Frekuensi Relatif Jenis}

$$
\mathrm{FR}=\left(\frac{\mathrm{Fi}}{\Sigma F i}\right) \times 100 \%
$$

dimana,

$\mathrm{Fi}=$ Frekuensi jenis ke-i

$\Sigma F=$ Jumlah frekuensi untuk jenis-i
Dominan Jenis (Di)

$$
\mathrm{Di}=\frac{\Sigma B A}{A}
$$

dimana,

$\mathrm{BA}=\pi \mathrm{d} 2 / 4(\mathrm{~d}=\mathrm{DBH}, \pi=3,14)$

$\mathrm{A} \quad=$ Luas total area pengambilan sampel (ha)

Dominan Relatif

$\mathrm{DR}=\left(\frac{\mathrm{Di}}{\Sigma D i}\right) \times 100 \%$

dimana,

$\mathrm{Di}=$ Dominasi Jenis-i $(\mathrm{m} 2 / \mathrm{ha})$

$\Sigma D i=$ Jumlah total Dominasi jenis $\left(\mathrm{m}^{2} / \mathrm{ha}\right)$

Indeks Nilai Penting

$I N P(\%)=K R+F R+D R$

Indeks Keanekaragaman

$\mathrm{H}^{\prime}=-\sum_{i=1}^{s} \mathrm{Pi} \ln \mathrm{Pi}$

dimana,

$\mathrm{S} \quad=$ Jumlah spesies

3) $\mathrm{Pi} \quad=n i / \mathrm{N}$

$\mathrm{ni} \quad=$ Jumlah individu dalam spesies

$\mathrm{N} \quad=$ Jumlah individu total

\section{Biomassa Tegakan dan Akar}

Salah satu metode yang dapat digunakan yaitu dengan metode non destruktif sampel. Metode nondestruktif merupakan metode yang dilakukan dengan 4) cara tidak memanen atau menebang pohon. Metode non desktruktif menganalisis komponen dari batang, cabang dan daun menggunakan persamaan allometrik, dimana variabel bebasnya adalah dimensi diameter 
batang dan variabel terikatnya adalah biomassa.

Pengukuran biomassa dilakukan dengan menggunakan persamaan allometrik dengan parameter diameter batang. Pendugaan biomassa berguna untuk mengetahui perubahan cadangan karbon di atmosfer ketika adanya hutan ditebang atau dibakar. Suatu ekosistem yang mempunyai nilai kerapatan tinggi dari suatu spesies pohon, biomassanya akan lebih tinggi bila dibandingkan dengan areal mangrove yang memliki kerapatan spesies yang lebih rendah (Isnaeni et al., 2019). Hitung biomassa tegakan dan akar mangrove dengan persamaan allometrik (Fourqurean et al., 2014).

$\mathrm{Wt}=0,251^{*} \rho^{*}(\mathrm{DBH})^{2.46}$ 9)

dimana,

$\mathrm{W}=$ Biomasa tegakan $(\mathrm{Kg})$

$\rho=$ = Densitas Batang $(\mathrm{g} / \mathrm{cm} 3)$

$\mathrm{DBH}=$ Diameter Batang $(\mathrm{cm})$

$\mathrm{Wb}=0,199 * \rho^{0.899 *}(\mathrm{DBH})^{2.22}$

dimana,

$\mathrm{Wb}=$ Biomasa akar $(\mathrm{Kg})$

$\rho=$ Densitas Batang $\left(\mathrm{g} / \mathrm{cm}^{3}\right)$

$\mathrm{DBH}=$ Diameter Batang $(\mathrm{cm})$

Nilai densitas kayu $(\rho)$ setiap jenis mangrove dapat dilihat dalam Tabel 1.

Untuk biomassa jenis $N$. fruticans dapat dihitung berdasarkan persamaan pada penelitian Matsui et al. (2014) dengan parameter nilai DBH (1,3 m) dan tinggi pelepah seperti berikut :

$\log D W=0,85 \times \log D^{2} L+1,54$ dimana,

$$
\begin{array}{ll}
\text { DW } & =\text { Berat Kering }\left(\mathrm{kg} \cdot \mathrm{m}^{-2}\right) \\
\mathrm{D} & =\text { Diameter }(\mathrm{m}) \\
\mathrm{L} & =\text { Length }(\mathrm{m})
\end{array}
$$

\section{Simpanan Karbon Biomassa}

Menurut Kepel et al. (2019), persentase kandungan karbon biomassa mangrove berkisar antara $42-52 \%$. Penelitian ini mengambil nilai tengah sebesar $47 \%$ untuk perhitungan simpanan karbon biomassa tegakan dan akar, sebagaimana juga dinyatakan oleh Prasetyo et al. (2017) :

$C=W \times 0,47$

Keterangan :

$\mathrm{C}=$ Jumlah karbon dalam biomassa $(\mathrm{kg})$

$\mathrm{W} \quad=$ Jumlah biomasa pada tegakan atas

mangrove $(\mathrm{kg})$

$47 \%=$ Ketetapan persentase kandungan karbon pada biomassa

\section{HASIL DAN PEMBAHASAN}

\section{Kondisi Ekosistem Mangrove di Pulau Payung}

Komposisi jenis mangrove yang ditemukan di Pulau Payung saat penelitian terdapat 11 jenis mangrove, diantaranya jenis $A$. alba, $A$. marina, $B$. sexangula, $K$. candel, $N$. fruticans, $R$. apiculata, $S$. caseolaris yang termasuk dalam kategori mangrove mayor dan jenis Aegiceras sp, E. agallocha, $X$. granatum, $A$. aureum yang termasuk dalam kategori mangrove minor. Mangrove mayor (mangrove sejati utama) tumbuh membentuk tegakan murni pada ekosistem mangrove, tidak ikut tumbuh pada tanaman darat, dan memiliki morfologi dan fisiologi sesuai dengan lingkungan. Mangrove minor (mangrove sejati tambahan) jarang tumbuh sebagai tegakan murni, dan biasanya tumbuh di tepian habitat mangrove (Tomlinson,

\begin{tabular}{|c|c|c|}
\hline No. & Spesies & Wood Density $(\rho)$ \\
\hline 1. & Aegiceras corniculatum & 0,5967 \\
\hline 2. & Aegiceras floridum & 0,76 \\
\hline 3. & Avicennia alba & 0,6987 \\
\hline 4. & Avicennia marina & 0,7316 \\
\hline 5. & Bruguiera gymnorhiza & 0,741 \\
\hline 6. & Bruguiera sexangula & 0,83 \\
\hline 7. & Excoecaria agallocha & 0.4288 \\
\hline 8. & Kandelia candel & 0,5272 \\
\hline 9. & Rhizophora apiculata & 0,8814 \\
\hline 10 & Rhizophora mucronata & 0,8483 \\
\hline 11. & Rhizophora stylosa & 0,94 \\
\hline 12. & Sonneratia alba & 0,6443 \\
\hline 13. & Sonneratia caseolaris & 0,5337 \\
\hline 14. & Xylocarpus granatum & 0,6721 \\
\hline 15. & Xylocarpus moluccensis & 0,6535 \\
\hline
\end{tabular}

Tabel 1.

Nilai Densitas Kayu $(\rho)$ 
Tabel 2.

Sebaran Jenis Mangrove Tiap Stasiun

\begin{tabular}{lcccccccc}
\hline JENIS & \multicolumn{7}{c}{ STASIUN } \\
\cline { 2 - 8 } & $\mathbf{1}$ & $\mathbf{2}$ & $\mathbf{3}$ & $\mathbf{4}$ & $\mathbf{5}$ & $\mathbf{6}$ & $\mathbf{7}$ & $\mathbf{8}$ \\
\hline Mayor & & & & & & & & \\
A. alba & + & + & + & - & - & - & - & - \\
A. marina & - & + & - & - & - & - & - & - \\
B. sexangula & + & - & + & - & - & - & - & - \\
K. candel & + & - & + & - & - & - & - & - \\
N. fruticans & + & - & + & + & + & + & + & + \\
R. apiculata & - & - & + & + & + & - & - & - \\
S. caseolaris & - & + & - & + & + & - & - & - \\
\hline
\end{tabular}

Minor

A. aureum Aegiceras sp.

E. agallocha

$X$. granatum

Keterangan : + (Ada) - ( Tidak Ada)

Tabel 3 .

Indeks Nilai Penting (INP)

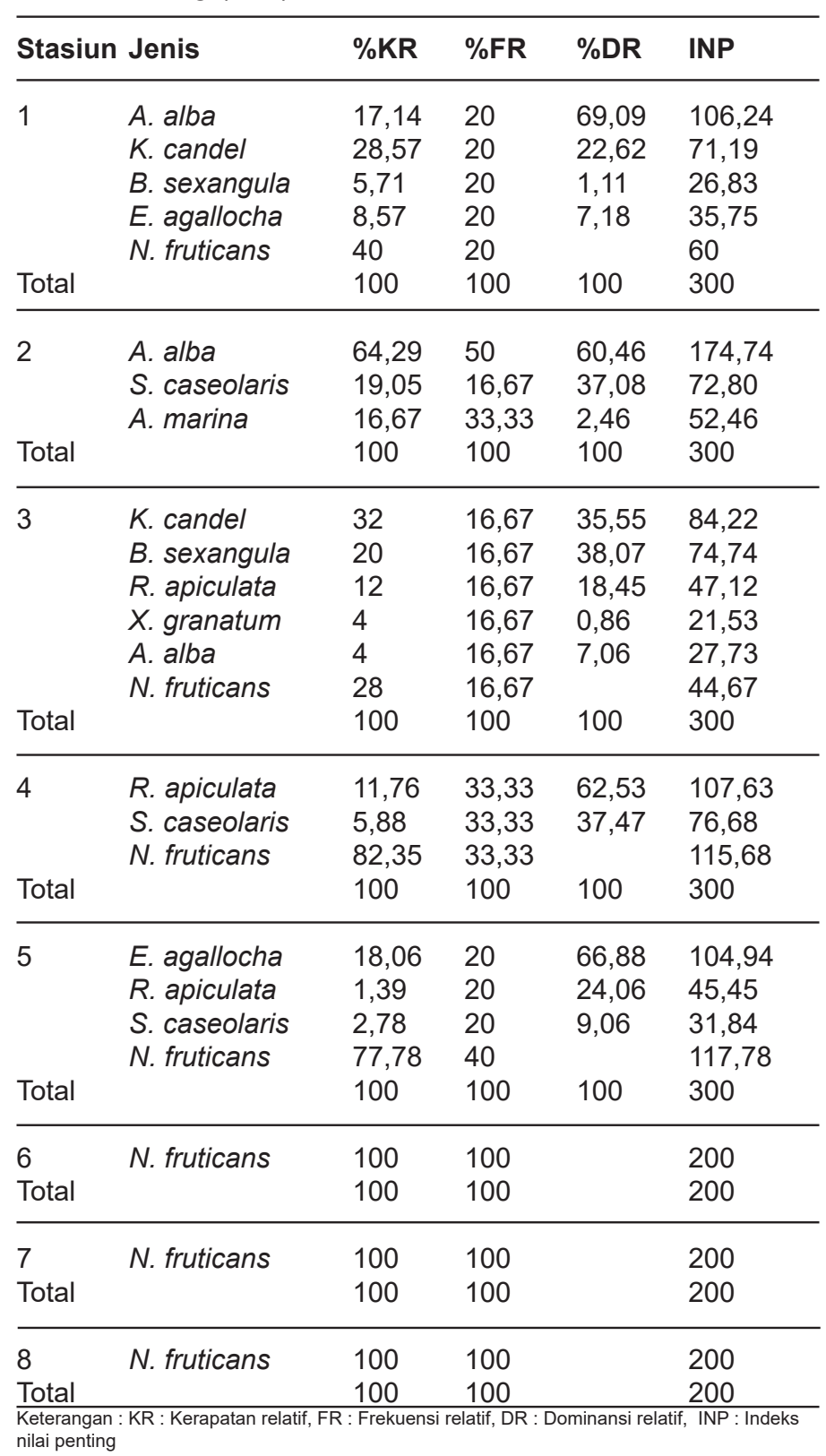


2016). Jenis mangrove yang sering dijumpai yaitu $N$. fruticans yang mendominasi kawasan Pulau Payung. Hal ini mengindikasikan bahwa ekosistem mangrove di Pulau Payung lebih banyak mendapat pasokan air tawar. Sebaran jenis mangrove disetiap stasiun dapat dilihat dalam Tabel 2.

Struktur komunitas mangrove berdasarkan perhitungan kerapatan relatif, frekuensi relatif, dominansi relatif dan indeks nilai penting (INP) serta indeks keanekaragaan (H'). Mengacu pada Keputusan Menteri Lingkungan Hidup No. 201 tahun 2004 Tentang Kriteria Baku dan Pedoman Penentuan Kerusakan Mangrove, pada stasiun 1, 2, 3, dan 6 memiliki nilai kerapatan mangrove dalam kategori sedang ( $\geq 1000$ -<1500 pohon per hektar) dan pada stasiun 4, 5, 7, dan 8 memiliki nilai kerapatan mangrove dalam kategori sangat padat ( $\geq 1500$ pohon per hektar).

Total kerapatan setiap jenis mangrove di Pulau Payung tertinggi dimiliki oleh jenis $N$. fruticans yaitu 12.067 ind/ha. Hal ini dapat disebabkan karena kondisi lingkungan di Pulau Payung dipengaruhi oleh pasang surut air laut yang tergolong ekosistem estuaria atau perairan payau sehingga sangat mendukung pertumbuhan jenis $N$. fruticans, sesuai dengan yang dinyatakan Noor et al. (2006) bahwa N. fruticans tumbuh dengan baik di perairan payau hingga hampir tawar. Kondisi perairan yang sama dengan Pulau Payung terdapat di kawasan pesisir Selatan Delta Mahakam, Kalimantan Timur dipengaruhi oleh pencampuran air tawar dan air laut sehingga kawasan ini juga didominasi oleh mangrove jenis $N$. fruticans yaitu seluas 4.822,5 Ha (Mursalin et al., 2014). Sebaran $N$. fruticans utamanya tumbuh di daerah equator dan biasanya membentuk komunitas murni yang luas di sepanjang sungai dekat muara hingga sungai dengan air payau, Indonesia memiliki areal Nipah terluas yaitu 700.000 ha dibanding Papua Nugini dan Filipina (Subiandono et al., 2011).

Total kerapatan terbesar selanjutnya adalah jenis A. alba sebanyak $1.150 \mathrm{ind} / \mathrm{ha}$. Hal ini dapat disebabkan jenis $A$. alba mampu beradaptasi pada kawasan yang selalu digenangi walaupun saat pasang rendah dan toleransi terhadap kadar garam. Sedangkan total kerapatan terendah dimiliki oleh jenis $X$. granatum yaitu 50 ind/ha, hal ini dapat disebabkan jenis $X$. granatum umumnya hidup pada kawasan yang lebih dekat ke daratan (Noor et al., 2006). Kemudian nilai total kerapatan untuk jenis vegetasi yang tergolong langka (endangered) di Indonesia yaitu $K$. candel (Suwignyo et al., 2008) sebanyak 733 ind/ha. Jenis K. candel merupakan mangrove yang toleran pada salinitas rendah (Shiau et al., 2016) dan tahan pada salinitas tinggi serta tumbuh di zona pasang surut di lautan tropis dan subtropis (Xing et al., 2019).
Nilai kerapatan relatif dan frekuensi realtif tertinggi terdapat pada jenis $N$. fruticans dan nilai dominansi relatif terdapat pada jenis A. alba sebesar 69\% (Tabel 3). Hasil indeks nilai penting (INP) menunjukkan nilai tertinggi berada pada jenis $N$. fruticans. Selanjutnya hasil analisis nilai indeks keanekaragaman ( $\left.\mathrm{H}^{\prime}\right)$ mangrove di Pulau Payung adalah 1,21. Nilai indeks di Pulau Payung pada penelitian ini lebih tinggi dibandingkan penelitian Afriyani et al. (2017) di Pulau Payung yaitu 1,16 dan lebih tinggi dari nilai ratarata indeks keanekaragaman mangrove di Sungai Sembilang dan Sungai Bungin, Kabupaten Banyuasin, masing-masing yaitu 1,13 dan 1,08 (Sarno et al., 2015).

\section{Biomassa dan Simpanan Karbon Tegakan dan Akar Mangrove \\ Biomassa dan Stok Karbon Tegakan Mangrove}

Dalam upaya menjaga kelestarian mangrove, maka sejak dini perlu diketahui potensi serapan atau simpanan karbon yang dimiliki oleh mangrove di suatu kawasan (Ulqodry et al., 2020). Berdasarkan hasil perhitungan biomassa dan simpanan karbon pada tegakan mangrove, jenis $A$. alba memiliki nilai biomassa terbesar yaitu 385,21 ton/ha dan simpanan karbon terbesar yaitu 181,05 tonC/ha. Nilai biomassa terbesar selanjutnya adalah jenis R. apiculata sebesar 203,52 ton/ha dengan simpanan karbon sebesar 95,66 tonC/ha. Nilai biomassa tegakan jenis $S$. caseolaris yaitu 192,14 ton/ha ind/ha dan stok karbon yang dimiliki S. caseolaris adalah 90,31 tonC/ha. Nilai biomassa tegakan jenis $B$. sexangula yaitu 61,72 ton/ ha dan simpanan karbon yaitu 29,01 tonC/ha. Nilai biomassa tegakan jenis $E$. agallocha yaitu 47,86 ton/ ha dan simpanan karbon yaitu 22,5 tonC/ha. Jenis $\mathrm{K}$. candel memilki nilai biomassa tegakan sebesar 52,88 ton/ha dan simpanan karbon sebesar 24,85 tonC/ha. Nilai biomassa jenis $N$. fruticans adalah 45,84 ton/ha dengan simpanan karbon $N$. fruticans sebesar 21,54 tonC/ha. Nilai biomassa terkecil berada pada jenis $X$. granatum yaitu 0,64 ton/ha dengan simpanan karbon 0,3 tonC/ha. Nilai biomassa dan simpanan karbon tertinggi dimiliki oleh jenis $A$. alba dikarenakan nilai kerapatan dan dominansi jenis juga besar.

Berdasarkan hasil perhitungan didapat bahwa nilai simpanan karbon dipengaruhi oleh biomassa mangrove, semakin besar biomassa maka semakin besar simpanan karbon. Besar kecilnya nilai biomassa dipengarahui oleh diameter batang, massa jenis kayu. Hasil perhitungan biomassa dan simpanan karbon tiap jenis tegakan mangrove di Pulau Payung dapat dilihat pada Gambar 3. Hasil perhitungan biomassa dan simpanan karbon di tiap stasiun menunjukkan nilai yang bervariasi. Nilai biomassa dan simpanan karbon tegakan terbesar berada di stasiun 2 yaitu 391,44 ton/ ha dan 183,98 tonC/ha yang di dominasi oleh jenis $A$. alba. Nilai biomassa dan simpanan karbon tegakan terbesar selanjutnya berada pada stasiun 4 yaitu 
179,67 ton/ha dan 84,44 tonC/ha.

Pada stasiun $6,7,8$ yang di dominasi jenis $N$. fruticans memiliki nilai biomassa dan simpanan karbon berturut-turut sebesar 4,1 ton/ha dan 1,93 tonC/ha, 11,31 ton/ha dan 5,31 tonC/ha, dan 12,74 ton/ha dan 5,99 tonC/ha. Nilai rata-rata biomassa dan simpanan karbon tegakan atas di setiap stasiun Pulau Payung adalah 124,4 ton/ha dan 53,8 tonC/ha. Hasil perhitungan biomassa dan simpanan karbon tegakan mangrove di tiap stasiun pengamatan di Pulau Payung dapat dilihat pada Gambar 4. Umumnya setiap jenis mangrove memiliki nilai biomassa yang berbeda karena kemampuan serapan dan penyimpanan karbon yang berbeda, hal ini dapat dianalisis berdasarkan nilai massa jenis pohon, diameter pohon atau tinggi pohon (Rahman et al., 2017). Biomassa pohon terbentuk dari senyawa karbohidrat yang dihasilkan dari fotosinstesis, terdiri dari unsur oksigen $(\mathrm{O})$, karbon $(\mathrm{C})$, dan hidrogen $(\mathrm{H})$, dimana sebagian besar biomassa terdiri atas karbon (Suryono et al., 2018) dan menyimpan karbon sebesar 47\% (Prasetyo et al., 2017).

\section{Biomassa dan Stok Karbon Akar Mangrove}

Berdasarkan hasil perhitungan biomassa dan simpanan karbon pada akar mangrove menggunakan metode allometrik, nilai biomassa terbesar dimiliki oleh jenis $A$. alba yaitu 141,09 ton/ha dan simpanan karbon terbesar yaitu 66,31 tonC/ha. Jenis $R$. apiculata memiliki nilai biomassa dan simpanan karbon akar terbesar ke-2 yaitu 74,17 ton/ha dan 34,86 tonC/ ha. Selanjutnya nilai biomassa dan simpanan karbon akar jenis S. caseolaris yaitu 70,19 ton/ha dan 32,99 tonC/ha. Kemudian jenis $X$. garanatum memiliki nilai biomassa dan simpanan karbon akar terkecil yaitu 0,35 ton/ha dan 0,16 tonC/ha. Sedangkan biomassa dan simpanan karbon akar pada jenis $N$. fruticans tidak dihitung. Hasil perhitungan biomassa dan simpanan karbon akar setiap jenis mangrove dapat dilihat pada Gambar 5.

Pada hasil perhitungan biomassa dan simpanan karbon akar tiap stasiun, nilai biomassa dan simpanan karbon akar terbesar berada di stasiun 2 sebesar 145,80 ton/ha dan 68,53 tonC/ha. Selanjutnya nilai biomassa dan simpanan karbon akar terbesar ke 2 berada di stasiun 4 yaitu 64,05 ton/ha dan 30,10 tonC/

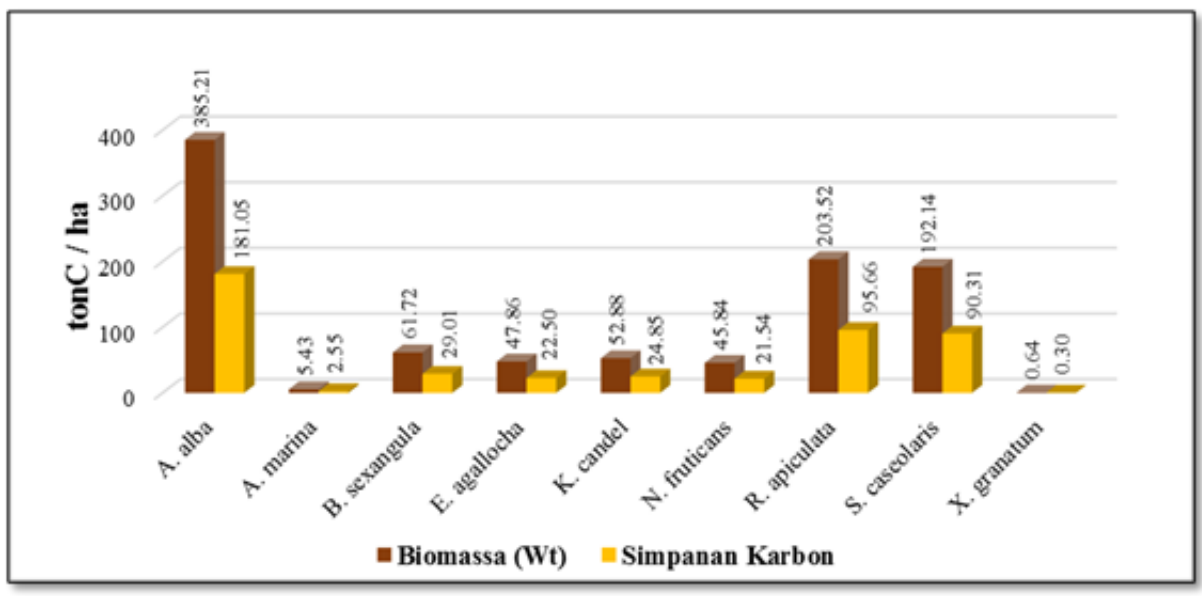

Gambar 3. Biomassa dan Simpanan Karbon Tegakan Tiap Jenis Mangrove.

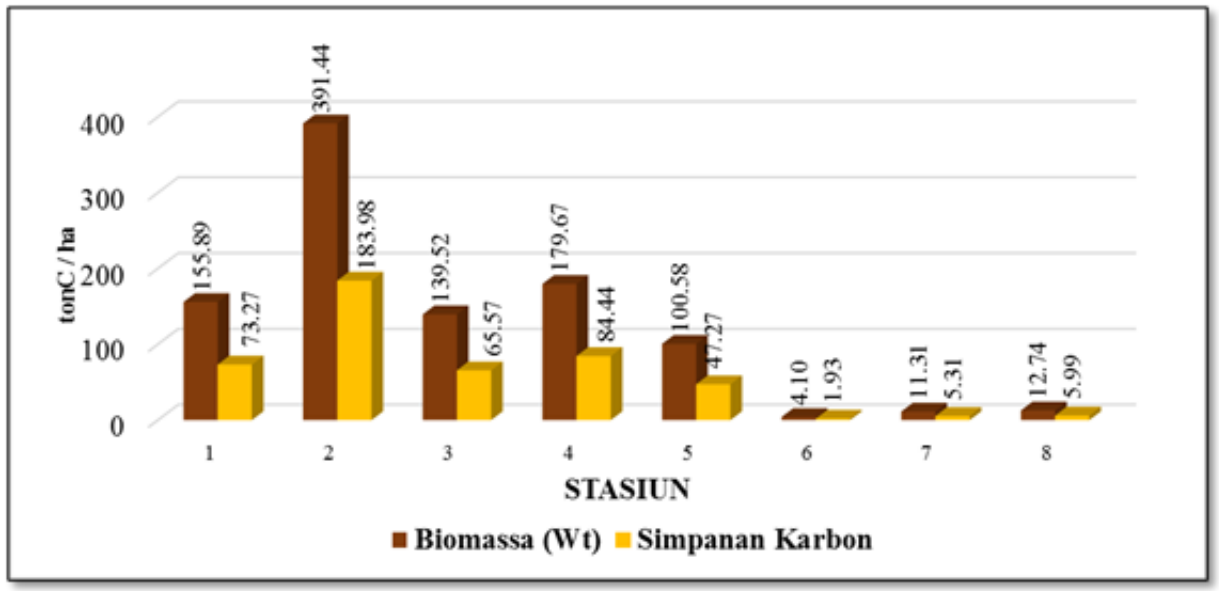

Gambar 4. Biomassa dan Simpanan Karbon Tegakan Mangrove Tiap Stasiun. 
ha. Sedangkan pada stasiun 5 memiliki nilai biomassa dan simpanan karbon akar terkecil yaitu 37,02 ton/ ha dan 17,40 tonC/ha. Nilai rata-rata biomassa dan simpanan karbon akar tiap stasiun adalah 71,44 ton/ ha dan 33,58 tonC/ha. Hasil biomassa dan simpanan karbon akar tiap stasiun disajikan pada Gambar 6.

Nilai rata-rata simpanan karbon akar mangrove di Pulau Payung lebih besar dibandingkan dengan penelitian Murdiyarso et al. (2015) di Taman Nasional Sembilang, Sumatera Selatan yaitu 27,9 MgC/ha, dan tidak jauh berbeda dari penelitian simpanan karbon akar Kepel et al. (2019) di Sulawesi Utara yaitu $10,78 \pm 44,20 \mathrm{MgC} / \mathrm{ha}$. Namun lebih besar dari penelitian simpanan karbon akar Suryono et al. (2018) di Jembrana, Bali yaitu sebesar 57,69 ton/ha. Tingginya nilai karbon biomassa mangrove dibandingkan daerah lain bisa dikarenakan memang kondisi nyata di lapangan, bisa juga dikarenakan penggunaan metoda non-destruktif melalui pendekatan allometrik. Menurut Adame et al., (2017), biomassa akar yang diestimasi dengan persamaan alometrik umum (Komiyama et al.,
2005) cenderung $40 \pm 12 \%$ lebih tinggi dari biomassa akar yang diukur langsung di lapangan. Hal ini bisa disebabkan karena ada ketidak pastian terkait dengan struktur yang terbangun di dalam tanah, dimana setiap jenis mangrove memiliki ke khasan sendiri.

Perbedaan nilai simpanan karbon pada mangrove disebabkan oleh perbedaan jumlah biomassa pohon, kesuburan tanah dan daya serap vegetasi yang berbeda (Ati et al., 2014). Sedangkan biomassa menurut Rachmawati et al. (2014) mangrove dipengaruhi oleh kerapatan, diameter, tinggi, dan berat jenis kayu. Hasil penelitian ini juga menunjukkan pola hubungan yang positif antara kerapatan mangrove dengan biomassa $(r=0,33)$ dan antara diameter mangrove dengan nilai biomassa $(r=0,68)$. Kepel et al. (2017) menyatakan bahwa hasil analisis perbandingan nilai biomassa antara bagian atas dan bawah pohon mangrove menunjukkan bahwa kontribusi karbon bagian bawah pohon mangrove lebih kecil dibanding bagian atas mangrove berkisar $29-45 \%$.

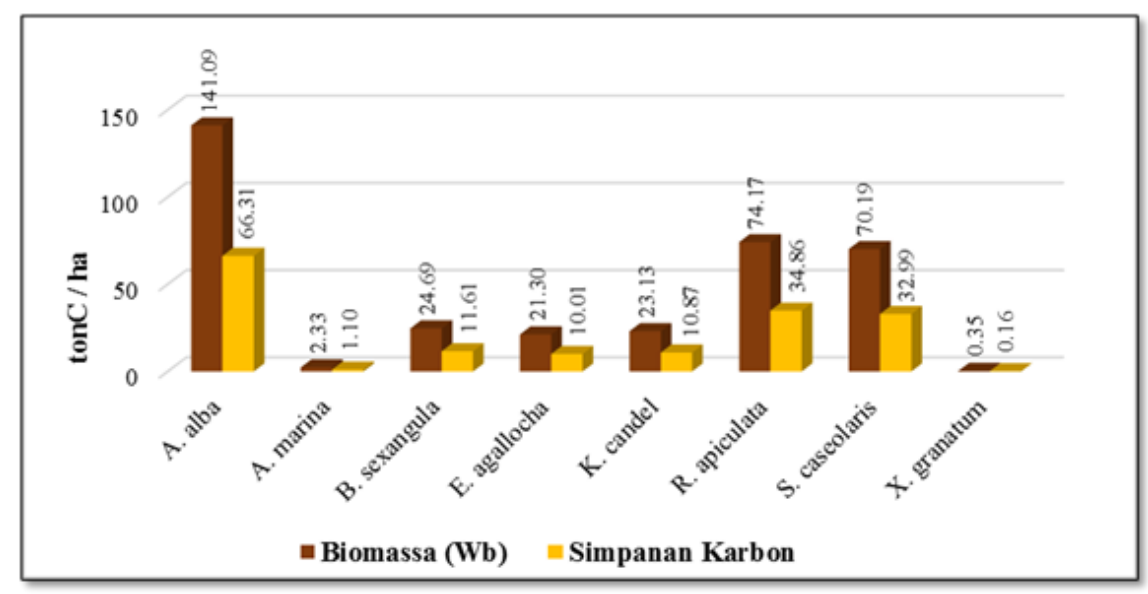

Gambar 5. Biomassa dan Stok Karbon Akar Tiap Jenis Mangrove.

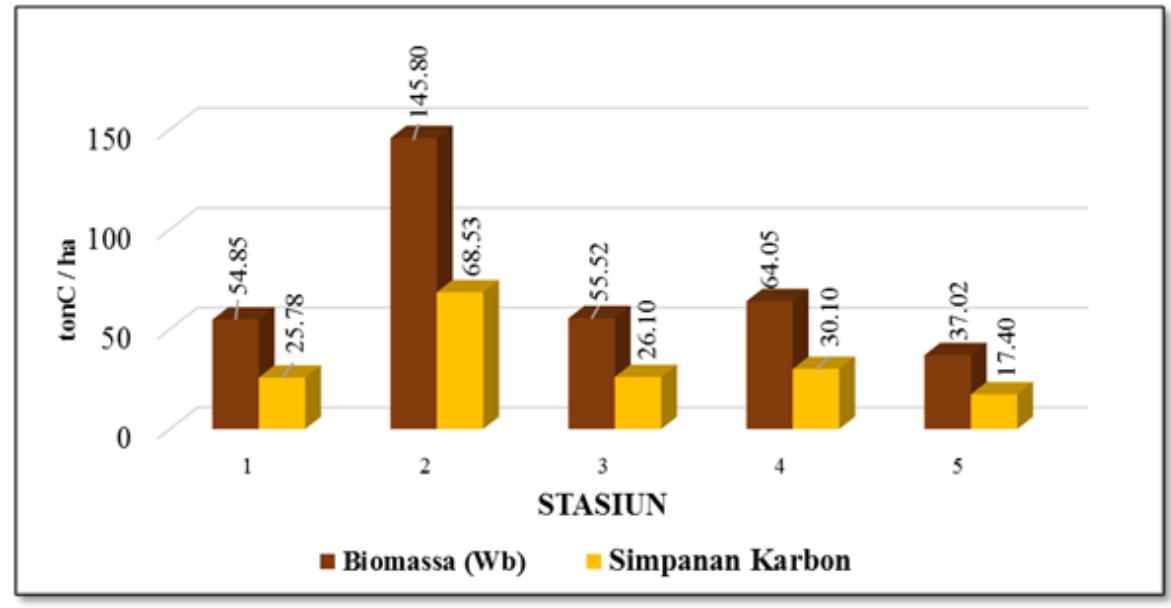

Gambar 6. Biomassa dan Stok Karbon Akar Mangrove Tiap Stasiun. 


\section{KESIMPULAN}

Berdasarkan hasil penelitian dapat disimpulkan bahwa pada tegakan mangrove memilki nilai rata-rata biomassa sebesar 124,4 ton/ha dan nilai rata-rata simpanan karbon sebesar 58,47 tonC/ha. Jenis $A$. alba memiliki simpanan karbon terbesar pada tegakan yaitu 181,05 tonC/ha dengan nilai biomassa tegakan sebesar 385,21 ton/ha. Pada akar mangrove memilki nilai ratarata biomassa yaitu 71,44 ton/ha dan nilai rata-rata simpanan karbon yaitu 33,58 tonC/ha. Jenis $A$. alba paling besar menyimpan karbon pada akar yaitu 66,31 tonC/ha dengan nilai biomassa akar sebesar 141,09 ton/ha. Semakin besar nilai biomassa pohon maka akan semakin besar simpanan karbon.

\section{PERSANTUNAN}

Penulis mengucapkan terima kasih kepada Universitas Sriwijaya yang telah mendanai penelitian ini. Selanjutnya terima kasih kepada pak Taher atas dukungan pengambilan sampel mangrove sehingga penelitian ini dapat terselesaikan dengan baik serta kepada semua pihak yang telah berkontribusi. Kontributor utama artikel ini adalah Septi Hermialingga dan Tengku Zia Ulqodry.

\section{DAFTAR PUSTAKA}

Adame, M.F., Cherian, S., Reef, R \& Stewart-Koster, B. (2017). Mangrove root biomass and the uncertainty of belowground carbon estimations. Forest Ecology and Management, 403: 52-60.

Asuk, S. A., Offiong, E. E., Ifebueme, N. M., \& Akpaso, E. O. (2018). Species composition and diversity of mangrove swamp forest in southern Nigeria. International Journal of Avian \& Wildlife Biology. 3(2), 159-164.

Ati, R.N.A., Rustam, A., Kepel, T.L., Sudirman, N., Astrid, M., Daulat, A., . . . Hutahaean, A.A. (2014). Stok Karbon dan Struktur Komunitas Mangrove sebagai Blue Carbon di Tanjung Lesung, Banten. Jurnal Segara. 10(2), 119-127. doi:10.15578/ segara.v10i2.23

Center, W.A. Wood Density. Retrieved from http:// www.dbworldagroforestry.org

Donato, D.C., Kauffman, J.B., Murdiyarso, D., Kurnianto, S., Stidham, M., \& Kanninen, M. (2011). Mangroves among The Most Carbon-rich Forests in The Tropics. Nature Geoscience. 4, 293-297.

Fourqurean, J., Johnson, B., Kauffman, J.B., Kennedy, H., Lovelock, C., \& Saintilan, N. (2014). Field
Sampling of Vegetative Carbon Pools in Coastal Ecosystems: Conservation International, Intergovernmental Oceanographic Comission of UNESCO, International Union for Conservation of Nature.

Imiliyana, A., Muryono, M., \& Purnobasuki, H. (2011). Estimasi Stok Karbon pada Tegakan Pohon Rhizophora stylosa di Pantai Camplong, Sampang-Madura. Jurusan Biologi, Fakultas Matematika dan IImu Pengetahuan Alam 1-14.

Isnaeni, R., Ardli, E.R., \& Yani, E. (2019). Kajian Pendugaan Biomassa dan Stok Karbon pada Nypa fruticans di Kawasan Segara Anakan bagian Barat, Cilacap. BioEksakta: Jurnal IImiah Biologi Unsoed. 1(2), 156-162.

Karimah. (2017). Peran Ekosistem Hutan Mangrove sebagai Habitat untuk Organisme Laut. Jurnal Biologi Tropis. 17(2), 51-58.

Kepel, T.L., Ati, R.N.A., Daulat, A., Rustam, A., Suryono, D.D., Sudirman, N., . . Hutahaean, A.A. (2019). Cadangan Karbon Ekosistem Mangrove di Sulawesi Utara dan Implikasinya Pada Aksi Mitigasi Perubahan Iklim. Jurnal Kelautan Nasional. 14(2): 87-94.

Kepel, T.L., Suryono, D.D., Ati, R.N.A., Salim, H. L., \& Hutahaean, A.A. (2017). Nilai Penting dan Estimasi Nilai Ekonomi Simpanan Karbon Vegetasi Mangrove di Kema, Sulawesi Utara. Jurnal Kelautan Nasional. 12(1), 19-26.

KepMenLH. (2004). Tentang Kriteria Baku dan Pedoman Penentuan Kerusakan Mangrove. 201.

Komiyama, A., Poungparn, S., \& Kato, S. (2005). Common allometric equations for estimating the tree weight of mangroves. Journal of Tropical Ecology, 21, 471-477.

Matsui, N., Okimori, Y., Takahashi, F., Matsumura, K., \& Bamroongrugsa, N. (2014). Nipa (Nypa fruticans Wurmb) Sap Collection in Southern Thailand II. Biomass and Soil Properties. Environment and Natural Resources Research. 4(4), 89-100.

Muller-Dumbois, \& Ellenberg, H. (1974). Aims and Methods of Vegetarian Ecology. London: John Willey \& Sons.

Murdiyarso, D., Purbopuspito, J., Kauffman, J. B., Warren, M. W., Sasmito, S. D., Donato, D. C., . . . Kurnianto, S. (2015). The Potential of Indonesian Mangrove Forests for Global Climate Change Mitigation. Nature Climate Change. 5: 1089-1092. doi:10.1038/NCLIMATE2734 
Mursalin, Nurjaya, I.W., \& Effendi, H. (2014). Analisis Sensitivitas Lingkungan OSCP (Oil Spill Contingency Plan) di Pesisir Selatan Delta Mahakam, Provinsi Kalimantan Timur. Jurnal Pengelolaan Sumberdaya Alam dan Lingkungan. 4(1), 84-95.

Mustofa, A. (2018). Praktik Pembibitan dan Revitalisasi Hutan Mangrove Pesisir Jepara. Journal of Dedicators Community UNISNU JEPARA. 2(1). 8-16.

Noor, Y.R., Khazali, M., \& Suryadiputra, I.N.N. (2006). Panduan Pengenalan Mangrove di Indonesia. Bogor: IUCN Regional Biodiversity Programme for South and Southeast Asia.

Prasetyo, D.P.B., Nuraini, R.A.T., \& Supriyantini, E. (2017). Estimation Carbon Stock on Mangrove Vegetation at Mangrove Area of Ujung Piring Jepara District. International Journal of Marine and Aquatic Resource Conservation and Coexistence. 2(1), 38-45.

Rachmawati, D., Setyobudiandi, I., \& Hilmi, E. (2014). Potensi Estimasig Karbon Tersimpan pada Vegetasi Mangrove di Wilayah Pesisir Muara Gembong Kabupaten Bekasi. Omni-Akuatika. 8(19), 85-91.

Rahman, Effendi, H., \& Rusmana, I. (2017). Estimasi Stok dan Serapan Karbon pada Mangrove di Sungai Tallo, Makassar. Jurnal IImu Kehutanan. 11: $19-28$.

Sarno, Suwignyo, R.A., Dahlan, Z., Munandar, \& Ridho, M.R. (2015). Primary Mangrove Forest Structure and Biodiversity. International Journal of Agriculture System. 3(2), 135-141.

Setiawan, H. (2013). Status Ekologi Hutan Mangrove pada Berbagai Tingkat Ketebalan. Jurnal Penelitian Kehutanan Wallacea, 2(2), 104-120.

Shiau, Y.-J., Lee, S.-C., Chen, T.-H., Tian, G., \& Chiu, C.-Y. (2016). Water Salinity Effects on Growth and Nitrogen Assimilation Rate of Mangrove (Kandelia candel) Seedlings. Aquatic Botany, 6.

Sondak, C. F. A. (2015). Estimasi Potensi Penyerapan Karbon Biru (Blue Carbon) oleh Hutan Mangrove Sulawesi Utara. Jurnal of Asean Studies on Maritime Issues. 1(1), 24-29.

Subiandono, E., Heriyanto, N.M., \& Karlina, E. (2011). Potensi Nipah (Nypa fruticans (Thunb.) Wurmb.) sebagai Sumber Pangan dari Hutan Mangrove.
Buletin Plasma Nutfah, 17(1), 54-60.

Suryono, Soenardjo, N., Wibowo, E., Ario, R., \& Rozy, E.F. (2018). Estimasi Kandungan Biomassa dan Karbon di Hutan Mangrove Perancak Kabupaten Jembrana, Provinsi Bali. Buletin Oseanografi Marina. 7(1), 1-8.

Suwignyo, R.A., Munandar, \& Sarno. (2008). Konservasi Kandelia candel sebagai Upaya Menjaga Biodiversitas Hayati Mangrove. Proceeding Seminar Nasional Biodiversitas II.

Tomlinson, P.B. (2016). The Botany of Mangroves: Cambridge University Press.

Ulqodry, T.Z., Matsumoto, F., Okimoto, Y., Nose, A., \& Zheng. S.H. (2014). Study on photosynthetic responses and chlorophyll fluorescence in Rhizophora mucronata seedlings under shade regimes. Acta Physiologiae Plantarum, 36, 19031917.

Ulqodry, T.Z., Suganda, A., Agussalim, A., Aryawati, R., \& Absori, A. (2020). Estimasi Serapan Karbon Mangrove Melalui Proses Fotosintesis di Taman Nasional Berbak-Sembilang. Jurnal Kelautan Nasional, 15 (2), 77-84

Xing, J., Pan, D., Wang, L., Tan, F., \& Chen, W. (2019). Proteomic and Physiological Responses in Mangrove Kandelia candel Roots Under ShortTerm High-Salinity Stress. Turkish Journal of Biology, 43, 314-325. 